$\xi=-1$

\title{
An Overview of Macro-Economic Determinants of Real Estate Price in Nigeria
}

\author{
Musa Abubakar Alkali ${ }^{1 *}$, Ibrahim Sipan ${ }^{2}$, Muhammad Najib Razali ${ }^{3}$ \\ ${ }^{1,2,3}$ Department of Real Estate, Faculty of Geoinformation and Real Estate, Universiti Teknologi Malaysia, 81310 UTM \\ Johor Bahru, Johor, Malaysia \\ *Corresponding author E-mail: abufatima34@gmail.com
}

\begin{abstract}
Understanding the relationship between real estate price and macroeconomic variables in developed countries is appreciated first by considering the housing role in the macro economy. In modern capitalist economy, real estate sector remains the most important element of aggregate demand. Since residential real estate comprises the bulk of country's tangible capital, the study on relationship between residential real estate price and macro economic variables are very significant for formulation of social and economic policies. The aim of this study is to examines the relationship between real estate residential price and macroeconomic variables in Nigerian economy. The study identified GDP, inflation rate, exchange rate, interest rate and crude oil price as the major determinants of real estate price in Nigeria and they have significant impact on real estate market in general.
\end{abstract}

Keywords: Macro-economic; Real Estate; Real Estate Price; Residential Real Estate

\section{Introduction}

The real estate residential markets in many developed countries globally has witnessed large recurring variations in real estate volumes and prices in the last few decades (Nneji et al. 2013). Macroeconomics is the overall movement and trends of the economy. A stable macroeconomic atmosphere will lead to expansion in the real estate market and for many reasons, the real estate market is different from other markets like goods and services (Ong, 2013b). Moreover, the real estate price dynamics have a close connection with market condition and macroeconomic variables (Guerrieri et al. 2010). Various economic theories shows that changes in nation's economy has an impact on real estate price and similarly changes in real estate price also has an impact on the economy (Meidani et al. 2011). According to Ciarlone (2015) unexpected collapse of real estate market might have a negative impact on macroeconomic conditions and nation's financial stability. Moreover, from the available literature real estate prices has a major impact on the nation's financial stability and macroeconomy, therefore, any structural breaks might change in the relation between stock and real estate markets (5). Macroeconomic is the movement of nation's economic condition. Residential real estate price is unlike other services and goods, therefore a well regulated and steady macroeconomic environment and policy will increase the real estate price (Kiat et al. 2015). Macroeconomic shocks for instance, unanticipated changes in the supply of money, changes of interest rate or industrial production affect real estate price prices with a lag determined by the speed of the propagation means (Adams and Füss, 2010). Moreover, shocks in the real estate price produce more effects on the macro-economy than shocks in the stock market. (Beltratti and Morana, 2010). Macroeconomic activities has direct impact on prices of assets since the risk-adjusted discount rates and cash flow of organizations chang- es with the condition of economy (9). The role of real estate market in the economy is very significant to monetary policy makers. Anticipations of tightening monetary policy in future, can lower the expected rate of real estate price appreciation and will raise users' capital cost of which would cause a decline in real estate demand and construction (Killins et al. 2017). According to Honchung (2018) real estate price cycles are quite independent which make them predictable by few number of macroeconomic time series. Whilst real estate price is a good in-sample forecaster for recurring variations in several macroeconomic time series, the performance of out sampling proposed that real estate price is suitable for forecasting limited sort of macroeconomic series. More so, real estate price fluctuations has a strong effect on economic activity, because real estate is the most significant element of household wealth, therefore real estate price changes can influence household expenditure and wealth (Granziera and Kozicki, 2015). Moreover, in a situation where Central Bank stabilizes the fluctuation of real estate price, this would lead to a greater stability of the macro economy. Similarly, the attempt of governments to stabilize real exchange rate and the conditions of credit market will also lead to greater stability (11). Banks plays an important role in the real estate price and increase in real estate price will not be observed without mortgage loans' increase. (Panagiotidis and Printzis, 2016). There are easier and more essential, reasons for studying the dynamics of real estate markets because of the important role real estate plays in modern civilization (Hirata et al. 2018).

\section{Relationship between Real Estate Price and Macro-Economic Variables}

The real estate sector remains a significant element of aggregate demand in modern economies (15). Macroeconomic changes can considerably determine the magnitude and direction of country's 
real estate price movements and it has important policy implications (Duan et al. 2018). According to Zhang et al. (2016) on the relationship between macro-economy and china's real estate price, revealed that interest and inflation rates has adverse impact on real estate price. Moreover, the influence of the macroeconomic growth on real estate price is generally positive. According to Grum and Govekar (2016) GDP, current account, share index, unemployment, and industrial production has relationship with residential real estate price in the capitals of the Poland, Norway, Greece and Slovenia. Real estate has a special significance from the perspective of macro-economy, similarly, the fluctuations of real estate price might have major consequences for global economy (19). He further added that, there is extensive literature on the finance and macro-economy which shows that financial variables might be regarded as a suitable predictors of inflation and economic activities. Moreover, recent findings revealed that asset prices might help in forecasting economic activities and inflation (19).

However, from the experience of advance economies, more empirical studies shows that real estate price and price changes has strong relationship with market specific conditions and a set of macroeconomic variables which are anticipated to influenced both the market side of supply (4). Similarly, according to Gasparènienè et al. (2016) high demand of residential real estate might cause speedy growth of real estate level. The Nigerian macroeconomic prospects has became low in the year 2014 with diminishing oil prices, deteriorating value of the currency and other features outweighing Nigeria's name as the largest Africa's economy. The rebasing of the economy in Nigeria revealed that the real estate contribution to GDP is higher than what was previously anticipated which shows 30 to $40 \%$ higher. The real estate is presently the 6th largest sector of the economy and is growing faster than the growth of average GDP. More so, macroeconomic features has significant impact on real estate price, because they influence the country's economy (Gasparenienè et al. 2016).

According to Ohno and Shimizu (2015) increase in real estate prices has been a global phenomenon and global liquidity has been indicated as a reason. The real estate market collapse and boom has great impact on the financial institutions' balance sheets than the discrepancy of security market and damaging effect of the boom on macro-economy. Moreover real estate price movements can influence the real part of the economy through their impact on the household balance sheets and financial system (Granziera and Kozicki, 2015). Therefore the relationship of real estate prices and the macroeconomic variables has been discussed in details as shows in Figure 1 below:

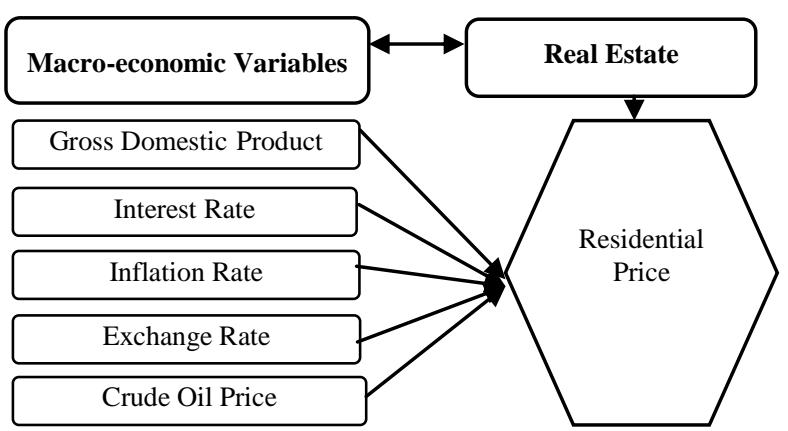

Fig. 1: Relationship between real estate price and macro-economic variables

\subsection{Relationship between Real Estate Price and Gross Domestic Product}

The growth of economy is determined by the increase in the size of a nation's economy because output is the extensive measure of the economic size. However, GDP is the most widely-used determinant of economic output (Wabomba et al. 2016). Moreover, gross domestic product (GDP) is among the most prominent indi- cators in macroeconomics which is used to represent economic condition. GDP is known as a prominent indicator due to the relation of real estate price with the macroeconomic activities. Activities related to real estate account for an important portion of household expenditures and GDP (Grum and Govekar, 2016). The relationship between real estate price and GDP has been an attractive issue in the past decades. High rate of growth on GDP represent consistency and reliability of economic condition and the main aim of every government is more focus on international transaction that occur efficiently. Therefore, it has impact on the cumulative demand level for investment to raise internally or foreign investment (Zhang et al. 2012). Tupenaite et al. (2017) reveled that macro-economy and real estate market has strong relationship at national and international level.

Moreover, at regional and national levels, real estate prices are strongly influenced by the economic cycles and therefore determined by essentials like income growth and GDP. Kimani and Memba (2017) examines the factors that affects real estate growth in Kenya, the outcome shows that GDP has a positive impact on the real estate growth. This means that for a nation to ensure that positive steps are made with regard to real estate then GDP advancement strategies should be followed which will guarantee that growing of the real estate is faster. It is very important for government to formed an economic development policies. Therefore, an accurate forecasting of GDP is essential to get an idea on the future trend of an economy (Wabomba et al. 2016). Figure 2 and 3 shows the Nigeria's real GDP growth and the contribution of real estate sector to the country's GDP.

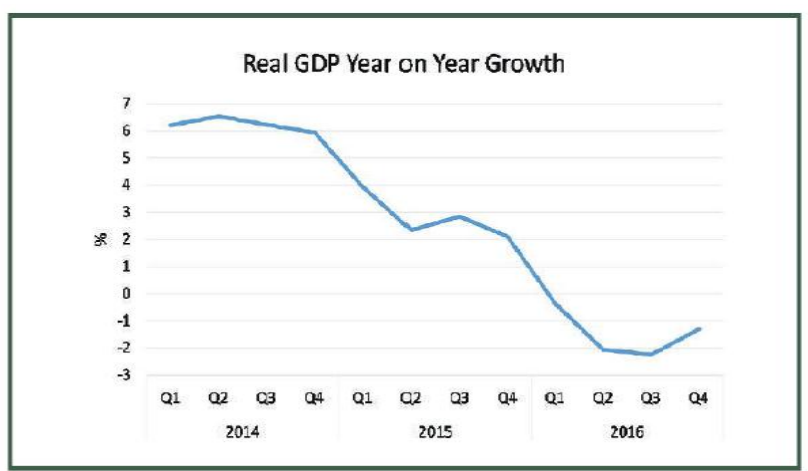

Fig. 2: Nigeria's Real GDP growth (Source: NBS, 2016)

\section{Real Estate Sector Contribution to GDP}

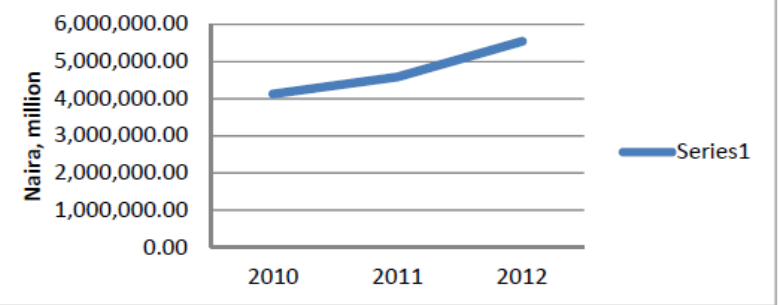

Fig. 3: Nigeria's real estate sector contribution to GDP ( NBS, 2016)

\subsection{Relationship between Real Estate Price and Interest Rate}

Bank loans affects real estate price through several liquidity outcomes. The real estate price is like asset price, it can be identified by the discounted future stream of cash flows. When the credit availability increases, the banks will provide lower loan rates and encourage future and current economic activities. However, in a situation where rate of interest rises, then the borrowing cost will also rises which will discourage the potential buyers and it will cause the housing demand to fall. Similarly, when the interest rate 
decreases, the user cost of real estate will decrease and the demand for real estate will rise (Panagiotidis and Printzis, 2016).

Moreover, the price of real estate is determined by the demand and supply of real estate. On the supply side, the relation between the interest rate and the supply of real estate will be negative. Investing in the real estates' early phase of development is significant and majority of investors obtain loan from banks. Therefore, if the interest rate increases, the cost of real estate investment will also increases and some real estate investors will reduce their investment scale, which will decrease the supply of real estate and increase the price (Zhang et al. 2016). Moreover, higher rate of interest has some consequences on the prices, where interest rate increase will have negative impact on the demand for housing, as the housing demand will be lower and it affects the direction of house prices (Almutairi, 2016). The rate of interest, has a negative effect both on the supply and demand sides of real estate market. Therefore, when the interest rate's effect on the real estate supply, is lower than the interest rate's effect on the real estate demand, the rate of interest will show a negative effect on real estate price. By contrast, where the interest rate's effect on the real estate demand is lower than the interest rate's effect on real estate supply, the rate of interest will show a positive impact on real estate prices (Zhang et al. 2016). Moreover, real interest rates, plays a double role, by identifying the financial cost (i.e. rate of mortgage) and serve as an indicator of the opportunity cost of owning a house (4). Interest rate is the main determinant of housing demand. The cost of gaining credit for hose purchase depends on the present level of interest rate. Higher interest rate increases cost of credit and reduces the housing demand and their prices (Almutairi, 2016). Shi et al. (2014) also examined the impact of central bank policies and retail mortgage rates on real estate prices in New Zealand between 1999 to 2009 . More so, it was discovered that the rate of interest have significant and positive relationship with estate prices, signifying that increase of policy rate might not be efficient in discouraging real estate prices. However, banks in states that witnessed large decline of real estate price might experienced high rates of loan default with high failure rate and low profit (27). Moreover, interest rate has adverse outcome on the growth of real estate. This entails that the government borrows on short run locally it discourages the growth rate of real estate because borrowing charges increases therefore the government should develop process of external borrowing to promote the growth of real estate growth (Kimani and Memba, 2017). The continued increase in the rate of interest since 2005 has noticeably hindered the of real estate market development in the U.S, where investment bank became bankrupt in the year 2008 due to extreme borrowing of financial instruments that were devalued because of a reduction in real estate prices (Park and Bae, 2015).

\subsection{Relationship between Real Estate Price and Inflation Rate}

According to Kimani and Memba (2017) increase in rate of inflation can lead to growth rate increase. Moreover, there are several factors that has impact on inflation increase. For example, increase in money borrowed can rises inflation although in some cases financing of real estate is through debt financing. Therefore inflation levels should be controlled to reduce the chances of cost increased as real estate market grows. Generally, assets demand is presumed to reflect the inflation trend in the economy, as inflation increases, in order for individuals to protect the acquiring power of their savings, they will prefer to keep their savings in assets as a hedge against inflation. Real estate assets are used by some individuals during inflation period. The inflation rate has direct influence on real estate price (Wang et al. 2012).

There is a strong connection between real estate price and inflation. During inflation, majority of things increases their price. However, the cost of construction will also increased and it will reduces the real estate supply in the market. It must be understood that, due to the global circumstances, that increase in money sup- ply may cause inflation and increase in real estate prices. Inflation is the continuous rises in the average price stage, which causes a decline in the money purchasing power. The purchasing power of money will declines due to inflation. Real estate was considered as an excellent hedge against inflation; therefore, investors will invest to protect the real estate value to boost the demand and increases the the prices up (Deng et al. 2016). Therefore, inflation can lead to a decline in real estate price, the inflation effect on real estate price will be both positive and negative (Zhang et al. 2016). However, inflation can be influence in a various way by change in the price of real estate. Firstly, real estate price increase will increases investment in real estate and building construction materials' demand will also increase, which might increase in the prices of these products and it can encourage the inflation level. Secondly, real estate price increase will make real estate owners to feel self-sufficient and expect increases their wealth, which will also increases the residents' expenditure and inflation level as well. Thirdly, real estate price increase, will raises the collateral value, this helps in expanding the bank credit volume, the higher the currency volume released, the higher the inflation level (Deng, 2010). Therefore, for every one that plan to buy a house, real estate price increase will raise the demand of repayment on residents, reduce inflation and control consumption. Generally, the impact of real estate price on inflation is uncertain (Zhang et al. 2016).

Therefore, any time government is planning on macroeconomic policies, they must predict the real estate growth rates' impact on future inflation in various cities. When the price of real estate prices increases fast, the government have to concentrate on the price level changes and should get ready for excessive price rise and employ efficient regulation over inflation (Zhang et al. 2016). Compared to other assets in capital market, the price of real estate does not change instantly after the economic news and usually show low fluctuation in price. The prices of real estate mainly show strong descending price stickiness since no one sells his property lower than a certain price during the period of recession. Therefore, real estate prices tend to decline during inflation rather than nominal price reduction (Adams and Füss, 2010). The rise of inflation is considered to cause increase in real estate prices along the sustained increase in the prices for goods and services (Gasparènienè et al. 2016).

Generally asset demand supposed to reflect the inflation trend of the nations' economy, people are usually keep their savings in assets as inflation increases, because they offer a hedge against inflation. Real estate are used by individuals during inflation. The inflation rate has direct influence on real estate price (Almutairi, 2016). As earlier anticipated, high inflation rates raises the real estate price, the higher rate of inflation, the price of real estate will be higher, of course the response of real estate prices to inflation rates may depend on numerous factors that include real estate supply, intensity of demand and market condition (Almutairi, 2016). Particularly, when taking the trend into account, it was discovered that inflation impact on housing returns is negative and the impact of housing returns on inflation is positive (30).

\subsection{Relationship between Real Estate Price and Ex- change Rate}

Exchange rate indicate the currency rate that will be traded for another. Moreover, exchange rate serve as the currency's strength, in addition, exchange rate reflects on the inflation consequences in economic perspective (Kiat et al., 2015). Therefore as the country's currency depreciates, foreign investors tends to invest in the country's real estate market. The higher demand of residential real estate in the affected country will lead to an increase in real estate price (Kiat et al. 2015). However, macroeconomic variables particularly, are the most significant determinant of exchange rates because they contribute about a third of the price variation in foreign exchange market (Ben Omrane and Savaşer, 2017).

Ohno and Shimizu (2015) examines the international capital flows' influence on real estate prices in some Asian countries. 
They determined the capital regulations and exchange rate influence on real estate prices. The outcome shows that fluctuation of the capital controls and exchange rate has the potential to increase real estate prices in Asia. Moreover, international excess liquidity has worsen the boom and collapse of global real estate markets in Asian countries. Ngo (2017) investigates how the returns of U.S real estate investment trusts (REITs) can be affected by the foreign exchange rate movements affect. REITs returns are affected negatively by U.S. dollar appreciation, regardless of the exchange rate changes, on the REIT size and of macro-economic features. Therefore REITs are not protected against foreign currency. Similarly, available literature on REITs focuses on inflation, interest rate and market factors as REIT returns determinants disregarding the fluctuations of exchange rate and oil price.

However, Yang and Zhiqiang (2012) analyzed the relationship between real estate prices and the foreign exchange rate between 2007 and 2010. The outcome revealed that an increase in real estate price will cause the despair of exchange rate, however, real estate has a positive effect on foreign exchange rate in China Moreover, with the increasing globalization of real estate investment performance, the connection between the exchange rate and the real estate price became close. The exchange rate appreciations and the increase in real estate price shows a kind of harmony situation. Increasing in exchange rate raises real estate market demand to retain the value of the assets, which sequentially increase the price of real estate (Meidani et al. 2011).

\subsection{Relationship between Crude Oil Price and Real Es- tate Price}

The global crude oil price in few decades has witnessed a severe fluctuations where the oil prices increases especially between 2003 and 2008 and 2008 the crude oil price attained \$147 per barrel but later dropped by $70 \%$. Due to the important role played by crude oil in economy the unstable crude oil prices has caused enormous shocks on economic development, particularly for countries that has relied on crude oil-importation (Zhang and Wang, 2015). The volatility of oil price markets recently encourages a reevaluation of the oil price shocks' effect on the real estate market and several mechanism of macro-economy (Killins and Egly, 2017).

Crude oil price has an impact on the trends of real. As the oil price increased, it would improve anticipations on accumulated demand and boasts the rate of return of various assets, especially real estate. Moreover, in oil based economy, private sector's role is limited because public sector dominated the economic activities by narrowing investment opportunities for private savings, which was regularly directed toward stock or real estate market. Where oil price increases, private savings will move towards restate investment and increases real estate demand and its prices. (Almutairi, 2016).

According to Nazlioglu et al. (2015) the demand and supply of oil price has negative effect on economic activity in developing and developed nations. Khiabani (2015) developed a macroeconomic model to examine the relationship between real estate market and oil inflows in oil exporting nation. The findings revealed that shock in the oil price explains a significant part of real estate market fluctuations. A positive shock in oil price, significantly increases real estate prices and the real estate stock. Previous studies revealed that both real estate price and oil price volatility are significant determinants of recessions (Breitenfellner et al. 2015). According to Yiqi (2017) change in oil price has affected Norway's economy. He discovered that prices of oil has major effect on the real estate prices, even though some countries does not rely mainly on oil industry, therefore fluctuation of crude oil prices does not influence their economy. According to Nazlioglu and Gormus (2016) oil prices has an important information in explaining the performance of real estate market. Breitenfellner et al. (2015) carried out an empirical analyses on the role of oil price increase on real estate prices from 18 OECD economies for a pe- riod of 37 years and discovered that rise of oil price is an important indicator on the dynamics of real estate prices. Therefore increase of oil price has significant impact on real estate bubble. Moreover, Robert et al. (2017) carried out a research on the oil shocks effect on real estate market in the United States and Canada and the outcome indicated that the nature of the oil demand and supply matters in determining the reaction of real estate market to the oil price changes. Moreover, the outcome is more relevant to the oil exporting countries than importing countries. Similarly, real estate price and the global oil supply is more stronger in Canada as an oil exporter compared to United States as oil importer.

Table 1: Summary of Literature on Real Estate and Macroeconomic Variables

\begin{tabular}{|c|c|}
\hline Author/Country & $\begin{array}{l}\text { Macro-economic variables and real estate } \\
\text { price }\end{array}$ \\
\hline $\begin{array}{l}\text { Nguyen and Wang } \\
(2010) \\
\text { Taiwan }\end{array}$ & GDP, CPI and housing price index (HPI) \\
\hline $\begin{array}{l}\text { Adams \& Füss }(2010) \\
(15 \text { OECD countries })\end{array}$ & $\begin{array}{l}\text { Interest rate, construction rate, economic } \\
\text { activity, money supply, real consumption, } \\
\text { industrial production, GDP, employment and } \\
\text { house price data }\end{array}$ \\
\hline $\begin{array}{l}\text { Beltratti and Morana } \\
\text { (2010) G-7 countries }\end{array}$ & house price shocks, stock market shocks \\
\hline Meidani et al. (2011) Iran & $\begin{array}{l}\text { GDP, consumer price index (CPI), exchange } \\
\text { rate and real house prices }\end{array}$ \\
\hline $\begin{array}{l}\text { Biłozor and Wiśniewski, } \\
\text { 2012) Europe }\end{array}$ & $\begin{array}{l}\text { GDP, unemployment rate, interest rates, } \\
\text { Consumer Prices Index, Adjusted Net Na- } \\
\text { tional Income, Population Growth, General } \\
\text { Government Debt, Long Term Loans and } \\
\text { Residential Property Prices Indices (RPPIs) }\end{array}$ \\
\hline Nneji et al. (2013) U.S & $\begin{array}{l}\text { Inflation, disposable income growth, short } \\
\text { rate, interest rates and housing price }\end{array}$ \\
\hline $\begin{array}{l}\text { Gaspareniene et al. } \\
(2016)\end{array}$ & $\begin{array}{l}\text { GDP, inflation rate, interest rate, bank loan } \\
\text { and housing price }\end{array}$ \\
\hline Zhang et al. (2016) China & $\begin{array}{l}\text { Housing price, Inflation, Interest rate and } \\
\text { Macroeconomic growth rate }\end{array}$ \\
\hline $\begin{array}{l}\text { Jadevicius (2016) Lithu- } \\
\text { ania }\end{array}$ & $\begin{array}{l}\text { housing market, building activity, interest } \\
\text { rates, inflation, and employment }\end{array}$ \\
\hline $\begin{array}{l}\text { Grum and Govekar } \\
\text { (2016) Europe }\end{array}$ & $\begin{array}{l}\text { Unemployment rate, current account, gross } \\
\text { domestic product and industrial production } \\
\text { and real estate price }\end{array}$ \\
\hline $\begin{array}{l}\text { Panagiotidis and Printzis } \\
\text { (2016) Greece }\end{array}$ & $\begin{array}{l}\text { House Price Index, Consumer Price Index, } \\
\text { Industrial Production Index, Retail trade } \\
\text { volume, interest rate, mortgage growth rate, } \\
\text { money supply and Unemployment rate }\end{array}$ \\
\hline $\begin{array}{l}\text { Killins et al. (2017) } \\
\text { Canada and U.S }\end{array}$ & Housing markets and oil price shocks \\
\hline $\begin{array}{l}\text { Kishor \& Marfatia } \\
\text { (2017) OECD }\end{array}$ & $\begin{array}{l}\text { Personal income, interest rates and housing } \\
\text { price }\end{array}$ \\
\hline
\end{tabular}

\section{Conclusion}

The research reviewed some previous empirical studies in the real estate market sector while considering the relationship between some macroeconomic variables with real estate residential price with a view to identified the most important macroeconomic determinants of real estate price. The reviewed literature identified five most important determinants of real estate price as: Gross Domestic Product; interest rate, inflation rate exchange rate and crude oil price. The strength and limitations of the previous studies shows that three out of five major determinants of real estate price were considered, such as GDP, interest rates and inflation rates, however, the relationship between real estate price and two other macroeconomic variables, such as exchange rate and crude oil price and household income were not covered. Moreover, majority of previous studies on the relationship between real estate price and macroeconomic variables largely were conducted in developed economies. However, from the available literature, such research was not conducted in developing economies and African real estate markets as well. Similarly most of the previous studies, considered house price indices instead of actual housing price, 
which shows that there is a need for further studies to consider the effect of macroeconomic variables on real estate price based on the actual price of different real estate residential types. Finally, government should encourage real estate investors, banks and other decision-makers, for sustainable investment in real estate market.

\section{Acknowledgement}

The author greatly acknowledge the School of post graduate studies UTM for the International doctorate fellowship grant as well as federal government of Nigeria for providing financial support to the postgraduate studentship through TETFUND intervention. The usage of used of University Teknologi Malaysia's research facilities are also acknowledged.

\section{References}

[1] Nneji O, Brooks C, Ward CWR. House price dynamics and their reaction to macroeconomic changes. Econ Model. 2013;32(1):1728.

[2] Guerrieri V, Hartley D, Hurst E. Endogenous Gentrification and Housing-Price Dynamics. 2010;(No. 10-08):1-40.

[3] Ali Akbar Naji Meidani, Maryam Zabihi MA. House prices , Economic Output, and Inflation Interactions in Iran House prices Economic Output, and Inflation Interactions in Iran. Res Appl Econ. 2011; Vol. 3, No(January 2015).

[4] Ciarlone A. House price cycles in emerging economies. Stud Econ Financ. 2015;32(1):17-52.

[5] Razali MN. The dynamic of returns and volatility of Malaysian listed property companies in Asian property market. Int J Strateg Prop Manag. 2015;19(1):66-83.

[6] KIAT GW, HAN HB, YET NC, HAO PK, HUI TS Macroeconomic and Financial Determinants of Malaysian Residential Property Market. 2015;(September).

[7] Adams Z, Füss R. Macroeconomic determinants of international housing markets. J Hous Econ. 2010;19(1):38-50.

[8] Beltratti A, Morana C. International house prices and macroeconomic fluctuations. J Bank Financ. 2010;34(3):533-45.

[9] Lai YW. Macroeconomic factors and index option returns. Int Rev Econ Financ. 2017;48(April 2015):452-77.

[10] Killins RN, Egly PV, Escobari D. The impact of oil shocks on the housing market: Evidence from Canada and U.S. J Econ Bus. 2017;93:15-28.

[11] Hon-chung H. HOUSING PRICE CYCLES AND AGGREGATE BUSINESS CYCLES : STYLISED FACTS IN THE CASE OF MALAYSIA Author ( $s$ ): Hon-Chung Hui Source: The Journal of Developing Areas , Vol . 47 , No . 1 ( Spring 2013 ), pp . 149-169 Published by: College of Business, Tenness. 2018;47(1):149-69.

[12] Granziera E, Kozicki S. House price dynamics: Fundamentals and expectations. J Econ Dyn Control. 2015;60:152-65.

[13] Panagiotidis T, Printzis P. On the macroeconomic determinants of the housing market in Greece: a VECM approach. Int Econ Econ Policy. 2016;13(3):387-409.

[14] Bureau TN, Press C. Global House Price Fluctuations : Synchronization and Determinants Author ( $\mathrm{s}$ ): Hideaki Hirata , M Ayhan Kose , Christopher Otrok and Marco E Terrones Source: NBER International Seminar on Macroeconomics , Vol . 9 , No . 1 ( 2012 ), pp . 119-166 Publi. Vol. 9. 2018. 119-166 p.

[15] Whelan S. Housing Markets and Macroeconomic Policy. Vol. 3, International Encyclopedia of Housing and Home. Elsevier Ltd.; 2012. 523-527 p.

[16] Duan K, Mishra T, Parhi M. Space matters: Understanding the real effects of macroeconomic variations in cross-country housing price movements. Econ Lett. 2018;163:130-5.

[17] Zhang H, Li L, Hui ECM, Li V. Comparisons of the relations between housing prices and the macroeconomy in China's first-, second- and third-tier cities. Habitat Int. 2016;57:24-42.

[18] Grum B, Govekar DK. Influence of Macroeconomic Factors on Prices of Real Estate in Various Cultural Environments: Case of Slovenia, Greece, France, Poland and Norway. Procedia Econ Financ. 2016;39(November 2015):597-604

[19] Ghorbani S. Forecasting the House Price for Ahvaz City: the Comparison of the Hedonic and Artificial Neural Network Models. 2017;5(19):29-45.
[20] Gasparènienè L, Remeikienè R, Skuka A. Assessment of the impact of macroeconomic factors on housing price level: Lithuanian case. Intellect Econ. 2016;10(2):122-7.

[21] Ohno S, Shimizu J. Do exchange rate arrangements and capital controls influence international capital flows and housing prices in Asia? J Asian Econ. 2015;39:1-18.

[22] Wabomba MS, Mutwiri MP, Fredrick M. Modeling and Forecasting Kenyan GDP Using Autoregressive Integrated Moving Average ( ARIMA ) Models. Sci J ofApplied Math Stat. 2016;4(2):64-73.

[23] Tupenaite L, Kanapeckiene L, Naimaviciene J. Determinants of Housing Market Fluctuations: Case Study of Lithuania. Procedia Eng. 2017;172:1169-75.

[24] Kimani NJ, Memba F. Factors Affecting the Growth of Real Estate in. 2017;4(2):531-49.

[25] Almutairi H, T E-SM. Determinants of Housing Prices in an Oil Based Economy. Asian Econ Financ Rev. 2016;6(5):247-60.

[26] Shi S, Jou JB, Tripe D. Can interest rates really control house prices? Effectiveness and implications for macroprudential policy. J Bank Financ. 2014;47(1):15-28.

[27] Wheelock DC. U . S . Regional Housing Busts of the 1980s and 1990s. 2006;413-30.

[28] Wang C-M, Lee H-M, Yang PH-C. The influence of macroeconomic variables on real estate-from the viewpoint of the middle class in Taipei. J Interdiscip Math. 2012;15(1):83-92.

[29] Deng Y, Girardin E, Joyeux R. Fundamentals and the volatility of real estate prices in China: A sequential modelling strategy. China Econ Rev. 2016;

[30] Nguyen TTB, Wang KM. Causality between housing returns, inflation and economic growth with endogenous breaks. J Chinese Econ Bus Stud. 2010;8(1):95-115.

[31] Ben Omrane W, Savaşer T. Exchange rate volatility response to macroeconomic news during the global financial crisis. Int Rev Financ Anal. 2017;52:130-43.

[32] Ngo T. Exchange rate exposure of REITs. Q Rev Econ Financ. 2017;64:249-58.

[33] Yang L, Zhiqiang H. on Correlation between RMB Exchange Rate and Real Estate Price based on Financial Engineering. Syst Eng Procedia. 2012;3:146-52.

[34] Zhang YJ, Wang J. Exploring the WTI crude oil price bubble process using the Markov regime switching model. Phys A Stat Mech its Appl. 2015;421(1):377-87.

[35] Robert N. Killins, Peter V. Egly DE. The Impact of Oil Shocks on the Housing Market: Evidence from Canada and U.S. J Econ Business, Forthcoming). 2017; No. 80529(44017).

[36] Nazlioglu S, Soytas U, Gupta R. Oil prices and financial stress: A volatility spillover analysis. Energy Policy. 2015;82(1):278-88.

[37] Khiabani N. Oil inflows and housing market fluctuations in an oilexporting country: Evidence from Iran. J Hous Econ. 2015;30:5976.

[38] Breitenfellner A, Crespo Cuaresma J, Mayer P. Energy inflation and house price corrections. Energy Econ. 2015;48:109-16.

[39] Yiqi Y. TUSING PRICES IN THE NorwegiHE EFFECT OF OIL PRICES ON HOan School of Economics Acknowledgment. 2017;

[40] Nazlioglu S, Gormus NA. Oil prices and real estate investment trusts ( REITs ): Gradual-shift causality and volatility transmission analysis. 2016;60:168-75.

[41] Renigier-Biłozor M, Wiśniewski R. The Impact of Macroeconomic Factors on Residential Property Price Indices in Europe. Aestimum 2012;(XLI Incontro di Studi del Ce.S.E.T.):149-66 